\begin{tabular}{c|l|l|l}
$\begin{array}{c}\text { Case Reports in } \\
\text { Gastroenterology }\end{array}$ & $\begin{array}{l}\text { Case Rep Gastroenterol 2011;5:122-124 } \\
\text { DOl: 10.1159/000326962 }\end{array}$ & $\begin{array}{l}\text { Published online: } \\
\text { April 6, 2011 }\end{array}$ & $\begin{array}{l}\text { O 2011 S. Karger AG, Basel } \\
\text { ISSN 1662-0631 } \\
\text { www.karger.com/crg }\end{array}$ \\
\hline
\end{tabular}

This is an Open Access article licensed under the terms of the Creative Commons AttributionNonCommercial-NoDerivs 3.0 License (www.karger.com/OA-license), applicable to the online version of the article only. Distribution for non-commercial purposes only.

\title{
Successful Endoscopic Removal of a Swallowed Toothbrush: Case Report
}

\author{
Ante Tonkic ${ }^{a, b} \quad$ Zoran Bogdanovic ${ }^{a} \quad$ Leo Grandićb

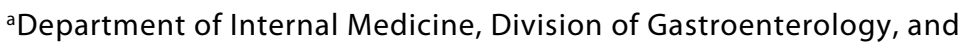 \\ ${ }^{\mathrm{b} S} \mathrm{School}$ of Medicine, University of Split, Split, Croatia
}

\section{Key Words}

Toothbrush · Flexible endoscopy · Polypectomy snare

\begin{abstract}
Most ingested foreign bodies will pass uneventfully through the gastrointestinal tract. Nevertheless, long and rigid foreign bodies are associated with an increased risk of gastrointestinal impaction, perforation and bleeding. Moreover, there has been no case of spontaneous passage of a toothbrush reported. Therefore, the prompt removal of such ingested foreign objects is recommended before complications develop. This case report describes a case of an 18-year-old woman who accidentally swallowed her toothbrush. The toothbrush was successfully removed via flexible endoscopy using a polypectomy snare. A swallowed toothbrush is a special clinical challenge. Early endoscopic retrieval of the toothbrush is critical for reducing morbidity and mortality. In cases when endoscopic removal fails, a laparoscopic surgical approach may be an alternative.
\end{abstract}

\section{Introduction}

The majority of swallowed indigestible foreign bodies pass through the gastrointestinal tract without complications [1-4]. However, there are three physiological narrowings involving the pylorus, duodenal C-loop and ileocecal valve [2]. Foreign bodies longer than $10 \mathrm{~cm}$, such as a toothbrush, cannot negotiate the duodenal C-loop due to its fixed retroperitoneal position [2]. These objects should be endoscopically removed as soon as possible to avoid pressure necrosis and gastrointestinal perforation [5-7]. If endoscopic removal fails or there is evidence of obstruction or perforation, laparoscopic gastrotomy should be performed [8]. 


\begin{tabular}{r|l|l|l} 
Case Reports in & $\begin{array}{l}\text { Case Rep Gastroenterol 2011;5:122-124 } \\
\text { DOl: 10.1159/000326962 }\end{array}$ & $\begin{array}{l}\text { Published online: } \\
\text { April 6, 2011 }\end{array}$ & $\begin{array}{l}\odot \text { 2011 S. Karger AG, Basel } \\
\text { ISSN 1662-0631 } \\
\text { www.karger.com/crg }\end{array}$ \\
\hline
\end{tabular}

\section{Case Report}

An 18-year-old Caucasian woman with no previous history of related medical problems was admitted to the Department of Internal Medicine, Division of Gastroenterology, Clinical Hospital Split because she had accidentally swallowed a toothbrush. The patient admitted she had been using the toothbrush to induce emesis. On presentation, $2 \mathrm{~h}$ after ingestion, she was asymptomatic and her vital signs were within normal limits. Chest and heart examination were unremarkable. The abdomen was soft, without tenderness or rigidity. A plain abdominal X-ray study confirmed the presence of the foreign body in the left upper abdominal quadrant (fig. 1). Informed written consent for upper gastrointestinal endoscopy was obtained from the patient and her parents. Esophagogastroduodenoscopy revealed the toothbrush in the stomach with its head positioned against the gastric fundus. The toothbrush was successfully removed using a polypectomy snare by grasping the toothbrush head. The procedure lasted $6 \mathrm{~min}$ and was uneventful. The extracted toothbrush was $20 \mathrm{~cm}$ long. Repeated upper gastrointestinal endoscopy was performed $4 \mathrm{~h}$ later and showed no evidence of mucosal lesion to the stomach or the esophagus. The patient was discharged home in excellent clinical condition after being observed for 6 hours.

\section{Discussion}

The majority of swallowed indigestible foreign bodies pass through the gastrointestinal tract without complications [2]. Foreign bodies in the stomach will pass uneventfully through the gastrointestinal tract in $80-90 \%$ of cases [1-3]. However, foreign objects longer than $10 \mathrm{~cm}$, such as a toothbrush, cannot negotiate the duodenal C-loop due to its fixed retroperitoneal position [2]. In such cases, these objects should be removed as soon as possible to avoid pressure necrosis and gastric perforation [2-5]. Removal of long foreign bodies from the stomach is influenced by the patient's clinical condition and technical abilities of the endoscopist [2-5]. Early endoscopy and removal is strongly recommended [2]. However, caution is required as well as extensive experience of the endoscopist [2]. If endoscopic removal fails or there is evidence of obstruction or perforation, surgical gastrotomy should be performed. There have been only a few successful toothbrush extractions, most from the esophagus [7]. Conscious sedation was used for toothbrush extractions from the stomach. We had no need for conscious sedation since the patient was actively participating during the procedure. Special attention has to be paid during the extraction of the toothbrush to its alongside alignment with the esophagus. This is especially important when pulling the object through the gastroesophageal junction. Otherwise, this most critical and demanding part of the extraction procedure may easily result in mucosal damage or foreign body impaction. The second important phase of the extraction procedure is when the foreign body reaches the oropharynx. The patient has to extend his head backwards and the endoscopist has to reach for the toothbrush with his hand and pull it out.

This case report describes a rare case in whom a toothbrush was safely extracted from the stomach endoscopically by snare extraction. The procedure is brief, does not require conscious sedation, and the patient can be discharged from hospital after a few hours.

\section{Conclusion}

A swallowed toothbrush is a special clinical challenge. It never passes through the gastrointestinal tract spontaneously. Early endoscopic retrieval of the toothbrush is 


\begin{tabular}{r|l|l|l}
$\begin{array}{r}\text { Case Reports in } \\
\text { Gastruenterology }\end{array}$ & $\begin{array}{l}\text { Case Rep Gastroenterol 2011;5:122-124 } \\
\text { DOI: 10.1159/000326962 }\end{array}$ & $\begin{array}{l}\text { Published online: } \\
\text { April 6, 2011 }\end{array}$ & $\begin{array}{l}\text { O 2011 S. Karger AG, Basel } \\
\text { ISSN 1662-0631 } \\
\text { www.karger.com/crg }\end{array}$ \\
\hline
\end{tabular}

critical for reducing morbidity and mortality. In cases when endoscopic removal fails, a laparoscopic surgical approach may be an alternative.

\section{Disclosure Statement}

The authors have no conflicts of interest to declare.

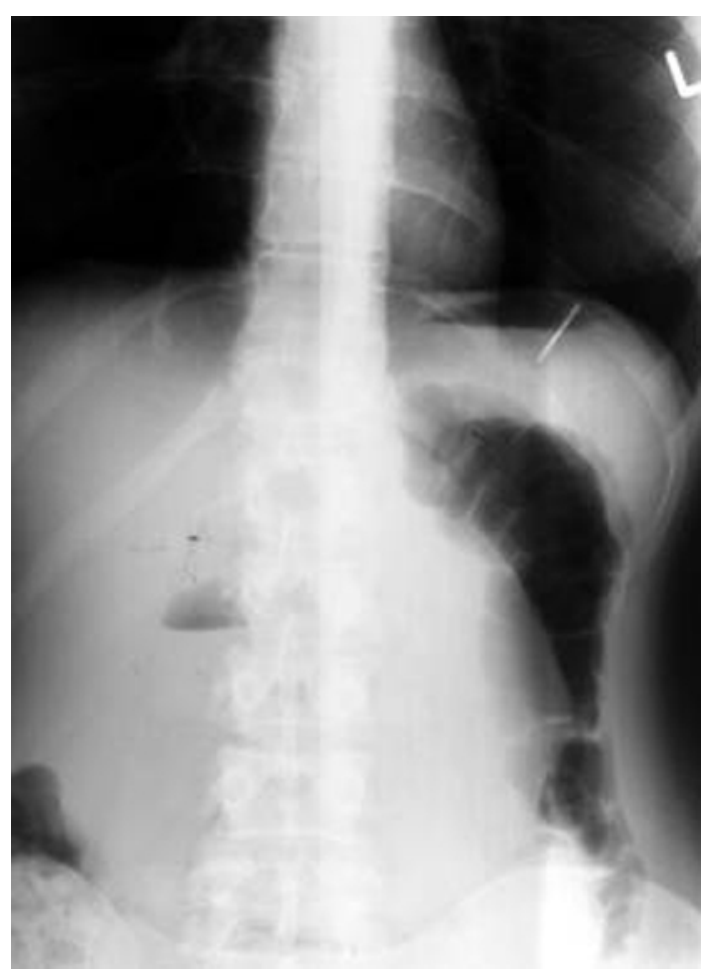

Fig. 1. Radiopaque part of the toothbrush in the stomach fundus.

\section{References}

$\checkmark 1$ Mughal M: Accidental ingestion of a toothbrush. Arch Emerg Med 1986;3:119-123.

-2 Eisen GM, Baron TH, Dominitz JA, et al: Guideline for the management of ingested foreign bodies. Gastrointest Endosc 2002;55:802-806.

3 Smith MT, Wong RK: Foreign bodies. Gastrointest Endosc Clin N Am 2007;17:361-382.

4 Li ZS, Sun ZX, Zou DW, Xu GM, Wu RP, Liao Z: Endoscopic management of foreign bodies in the upper-GI tract: experience with 1,088 cases in China. Gastrointest Endosc 2006;64:485-492.

5 Conway WC, Sugawa C, Ono H, Lucas CE: Upper GI foreign body: an adult urban emergency hospital experience. Surg Endosc 2007;21:455-460.

6 Chinitz MA, Bertrand G: Endoscopic removal of toothbrushes. Gastrointest Endosc 1990;36:527-530.

7 Lu XL, Cao HL, Qian KD: Removal of an accidentally swallowed toothbrush. Intern Med 2008;47:1797-1798.

-8 Wishner JD, Rogers AM: Laparoscopic removal of a swallowed toothbrush. Surg Endosc 1997;11:472-473. 